\title{
O Sopro Divino: Animação, Boneco e Dramaturgia
}

\author{
Felisberto Sabino da Costa
}

$\int^{n}$ ntre os afrescos que se encontram no teto da Capela Sistina, destaca-se um que detém nosso olhar, que apela ao toque, e que foi nomeado $A$ Criação de $A$ dão. Nele se vê a figura divina estendendo sua mão para um homem localizado num plano mais abaixo. Trata-se de Adão. Michelângelo representou-o com o rosto em perfil, retribuindo o olhar significante de Jeová, no qual parecem espelhar-se as intençóes do Deus. Adão está despido, corpo apoiado no chão, ressaltando-se as articulaçōes e a forma corpórea, dotada de uma musculatura definida. A sua mão toca o dedo do criador, cujas vestes parecem flutuar em companhia de anjos celestiais. Em suma, o pintor tem nas mãos o instante em que Adão é "animado" por Deus.

Entre as várias leituras possíveis dessa obra, evidencio as que dizem respeito ao conhecimento, à iluminação e à ânima ali configurados. Percebe-se ao fundo da criatura divina uma forma ligeiramente oblonga, assemelhada ao cérebro humano. A paisagem circundante contém somente os elementos essenciais ao quadro. Analisada sob a ótica do teatro de animaçáo, a cena se ilumina. A imagem idealizada por Michelângelo demonstra a criação em seu mais amplo sentido, em particular, no próprio ato da animação. A representação pictórica é síntese e abundância, qualidades que configuram também o oficio do ator-manipulador ou animador em toda a sua plasticidade. Uma imagem eficaz converte-se em estrutura dramática.

O encontro das duas mãos revela espírito e matéria, portanto, conflito. A mão do criador é o elemento que se destaca do contorno cerebral, povoado com anjos-personagens em latência. Portadora do sopro divino, chama para si a criatura. Nota-se, contudo, que o pintor não se limitou a mostrar-nos apenas a mâo do criador, mas todo o seu corpo, que participa de igual modo do ato da manipulação-animação do homem. Deve-se entender manipular, em seu sentido etimológico de engendrar: gerar, produzir, dar origem (Cunha, 1982: 298-498). Em suma: animar. Deus está animando o primeiro homem, ou seja, preenchendo-o com alma, espirito, mente, valor, coragem e força (Cunha, 1982: 82). Adão está nu, prostrado como "objeto", tornando-se "sujeito dramático" através da mão de Deus. Dramático no sentido grego do termo: açáo presente, o ser enquanto sendo compartilhado por atores e público. Nesta perspectiva, Deus é ator, "agente do ato", corporificado no personagem Jeová. É também manipulador ou animador, pois engendra o homem. Assim,

Felisberto Sabino da Costa é professor do Departamento de Artes Cênicas da ECA-USP. 
ator e manipulador são conceitos que não devem ser pensados separadamente, uma vez que para manipular/animar é necessário ser Deus, isto é, ator ${ }^{1}$.

Pensando-se na correspondência Deushomem, exposta no afresco, nossa proposta é tomá-la como paradigma para a construção da correlação animador-objeto Destarte, algumas questóes práticas podem ser lançadas a respeito de manipulação, boneco/objeto e dramaturgia.

\section{A Arte da Animaçăo no Teatro}

Ainda com o foco na visáo luminosa da cena, começamos por destacar nela o papel dos corpos presentes. Experiências com o corpo são essenciais ao ator-manipulador e podem ser divididas em corpo-totalidade e corpo-segmento. Considerando que o homem é feito à imagem e semelhança do seu criador, postulamos que o mesmo fenômeno ocorre com o boneco em relação ao homem. O boneco é constituído de partes que configuram uma totalidade, tal qual o seu criador. Enquanto manipulador, o ator compartilha com o boneco sua experiência de vida, doando-lhe os seus atributos vitais.

No afresco de Michelângelo, o corpo divino está presente, e o que atrai nosso olhar é a representação do instante mítico da criação. No palco, a presença do criador só pode ser entrevista no corpo animado do boneco - $\mathrm{O}$ atormanipulador, ao experenciar processos cinestésicos em seu próprio corpo - liberdades e restrições dos movimentos - estará compreendendo o universo cinético da sua criatura: o boneco. Havendo cumplicidade, a doação torna-se mais rica. É necessário ao ator-manipulador conscientizar-se da presença do seu corpo, para que possa trabalhar melhor a sua ausência. É no aparente paradoxo ausência-presença que se fundamenta o trabalho corporal do ator enquanto animador/manipulador. Corpo é volume, conforme podemos constatar em Michelângelo: $A s$ suas figuras têm três dimensóes... Adão torcendo a bacia, volta-se com elegância; os músculos contraem-se amplamente, tendo certos volumes sido valorizados, para dar uma melhor impressão de leveza natural ... o corpo torna-se para ele uma linguagem, não copia, cria (Upjohn, 1965: 125-6). Assim, o ator-manipulador experiencia em seu corpo os possíveis movimentos que realizará com o boneco. É necessário trabalhar as partes posteriores, anteriores e laterais do corpo, bem como a atuaçáo da força da gravidade. Cabe ao ator-animador, vencer a força da gravidade que tende a desalinhar o boneco e, mediante o binômio equilíbrio-desequilíbrio, lidar com a influência da força-peso gravitacional. Entre os fatores envolvidos para mantermo-nos de pé, está inclusa a noção de eixo corporal, que será transferida ao boneco quando da sua animação. $\mathrm{Na}$ manipulação, manter a verticalidade não significa deixá-lo ereto como um pedaço de madeira, mas trabalhar o eixo do boneco ao andar, levantar, correr, deitar etc. O eixo auxilia a manter a ilusáo de vida.

É importante que o ator-manipulador tenha consciência da sua respiraçáo e de como é necessária a transferência desse conceito ao boneco. Mesmo parado, o boneco precisa ter vida, caso contrário será somente um objeto inerte em cena. Para o ator, a respiração é um movimento vitalício contínuo, embora possa haver algum controle; entretanto, para o boneco, é mister o ator-manipulador torná-la presente durante o processo de manipulação, configurando-a num movimento sutil. Além de respirar, o boneco

1 Existem algumas práticas atomísticas em que a correlação ator e manipulador tendem a uma concepção mais diluída destes dois fatores, como, por exemplo, o teatro japonês Bunraku e algumas encenaçóes do Grupo Giramundo. 
necessita pulsar como uma estrela, emitindo luz e irradiando existência. Para o ator, o impulso é a energia interna da qual se origina o movimento, e é essa idéia que deve estar presente na manipulação do boneco, possibilitando a quem o observa acreditar na sua realidade física. Se o ato de criação se dá, a platéia compraz-se em perceber o momento do impulso e a efetivação do gesto. É um instante mágico porque pleno de vida. As experiências que têm como foco o corpo do ator-manipulador sáo úteis quanto a clareza e precisão dos movimentos porque permitem-no compreender que a manipulação de um boneco pode ter como referencial a estrutura do corpo humano, sem que se constitua uma simples cópia de seus movimentos. $O$ trabalho corporal proporciona a utilização do tônus adequado à manipulação. Muitos atores-manipuladores acabam colocando tensão desnecessária nas mãos ou em outras partes do corpo, emperrando a fluidez dos seus movimentos e, consequentemente, os do boneco.

Além do trabalho com o corpo-totalidade, é aconselhável dedicar-se ao corpo-segmentaçáo. $\mathrm{O}$ ator-manipulador organiza o seu corpo de acordo com a técnica em questão, podendo expressar-se num ritmo e manipular o objeto em outro, elaborando diversas formas de dissociação. $O$ ator necessita tornar o corpo apto para a manipulação, qualquer que ela seja. $O$ objetivo dessa dinâmica é explorá-lo visando outras possibilidades de movimentação e sensação. Segmentar o corpo é direcioná-lo para um determinado propósito. Neste sentido, é importante observar que: uma derivação devida à diminuição do espaço forçará a passassem ao mimo das mãos e à marionete. LECOQ, 1987: 20 Desta forma, pode-se ampliar e reduzir o campo de atuação do corpo como participante na anima- ção. Embora não seja a única possibilidade para animar um objeto, a mão desempenha um papel fundamental.

Acredito ser um suporte valioso para o ator-manipulador o conhecimento do Método Laban ${ }^{2}$. Conforme ele observa: talvez não seja muito inusitado introduzir aqui a idéia de se pensar em termos de movimento, em oposição a se pensar em palavras ... este tipo de pensamento não se presta à orientação no mundo exterior, como o faz o pensamento através das palavras, mas antes aperfeiçoa a orientação do homem em seu mundo interior, onde continuamente os impulsos surgem $e$ buscam uma válvula de escape, no fazer, no representar e no dançar (Laban, 1978: 42). Esse referencial é útil ao ator que trabalha com teatro de animação, uma vez que movimento e imagem fazem o teatro de bonecos (Amaral, 1993: 73).

No teatro de animação, o objeto plástico permeia a interface ator-platéia. Há de se considerar a relevância desse signo visual relaciona$\mathrm{da}$ à neutralidade do ator-animador. O objeto é que faz a mediação entre o ator-manipulador $e$ o público. Ele é o foco da ação. Isso não impossibilita que em determinado momento o animador tome para si essa posição. Em Michelângelo, Deus anima o homem, ato que é direcionado a um provável espectador. Entre este e Deus interpōe-se Adão.

$O$ ator-manipulador trabalha com os conceitos de falta e preenchimento. Ao boneco, falta a chama essencial, ou seja, movimento, vida. Ele é o Adāo-objeto estendido na montanha. $\mathrm{O}$ ator-animador é Jeová, o portador da energia que fluirá pela sua mão animando o objeto. Assim, o ator-manipulador lida com o preenchimento. Ele é o responsável pelo "sopro divino" que animará o boneco. A centelha que deflagra o processo.

2 Há outros trabalhos corporais bastante eficazes, como o Ai Ki Do, técnica marcial que envolve harmonia e energia vital, o processo desenvolvido por Klauss Vianna, alguns exercícios preparatórios do balé clássico entre outros. 
O ator-manipulador deve observar o foco-olhar do boneco. O olhar de Adão é preciso. No seu perfil, ressalta-se também o nariz, que é fundamental no processo do olhar do boneco. Adão parece mirar o Criador, contrafeito, como se soubesse que a vida comporta muitas atribulaçôes (Upjohn, 1965: 124-5). O olhar funciona como um farol, sinalizando o caminho a ser trilhado pela platéia, o terceiro elemento integrante do fenômeno da animação. Conforme já observara Stanislavski em suas experiências relacionadas ao ator: os olhos são o espelho da alma (Stanislavski, 1967: 195). O mesmo se pode dizer do olhar do boneco: é o espelho da sua ânima.

Na técnica japonesa Bunraku, o manipulador-mestre é quem segura a cabeça do boneco. Esta é considerada a sua parte principal. Em Deus, Michelângelo coloca o cérebro na ato da criação. Isto é bastante significativo, pois é o ator-manipulador quem "preenche" a cabeça do boneco, que não permanece ausente, no sentido de estar limitado somente aos movimentos. $O$ pensamento constitui-se num fluxo ininterrupto de imagens, conectado à vida do boneco e dialogando interiormente com este.

Deus e Adão estão sintonizados durante $o$ ato da criação. Percebe-se uma sintonia fina entre o sujeito Deus e o objeto Adão. A reciprocidade dos olhares é um indício dessa relação criadora e criativa. Da mesma forma, o atormanipulador permanece pari passu com o boneco. Caso contrário, um ou outro estará morto em cena.

Em Michelângelo não há gestos desnecessários, somente precisão. Gestos exatos enriquecem a movimentação do boneco, eles constituem dramaturgia. Há de se ter o cuidado com a simples ilustração gestual de um texto por intermédio do boneco, redundando-se num pleonasmo involuntário. Em $A$ Criação de Adão, Michelângelo coloca em cena somente atores imprescindíveis. Não há gratuidade em sua elaboração. Da mesma forma, o boneco é utilizado pela sua necessidade e essencialidade. Em cena, ele surpreende com gestos, situaçóes e palavras.

Ao ator-manipulador é indispensável experimentar. Michelângelo ousa ao trabalhar na Capela Sistina: Um feito fisico sem precedentes, sua conclusão transformou-o de uma certa forma, no primeiro pintor 'moderno', sendo que tanto a concep̧̧ão quanto a execução eram obra de uma única pessoa (Upjohn, 1965: 39). A Criação do Homem pode ser lida como criação divina e humana, uma vez que Michelângelo é o criador que dá vida ao toque divino ao representá-lo. Posto que a vida flui num movimento contínuo, o mesmo deve se dar com o teatro que se faz vida. $\mathrm{O}$ ator-animador lida com o imponderável, tomando-o possível, transformando o ato de animar numa experiência epifânica, consciente de que tudo o que ocorre no momento é teatro, tão somente teatro, mas animado, vivo! 


\section{Referências Bibliográficas}

AMARAL, Ana Maria. Teatro de Formas Animadas. São Paulo, Edusp, 1993. Teatro de Animação. São Paulo, Ateliê Editorial, 1997.

CUNHA, Antônio Geraldo. Dicionário Etimológico da Língua Portuguesa. Rio de Janeiro, Nova Fronteira, 1982.

GILLES, Annie. Le Jeu de la Marionnette. Nancy, Presses Universitaires, 1987.

GIRAUD, P. A Linguagem do Corpo. São Paulo, Ática, 1993.

LABAN, Rudolph. Dominio do Movimento. São Paulo, Summus, 1978.

LECOQ, Jacques. Le Théatre du Geste. Paris, Bordas, 1987.

STANISLAVSKI, Constantin. A Preparação do Ator. Rio de Janeiro, Civilização Brasileira, 1967.

UPJOHN, E. M. et alii. História Mundial da Arte. Lisboa, Bertrand, 1965.

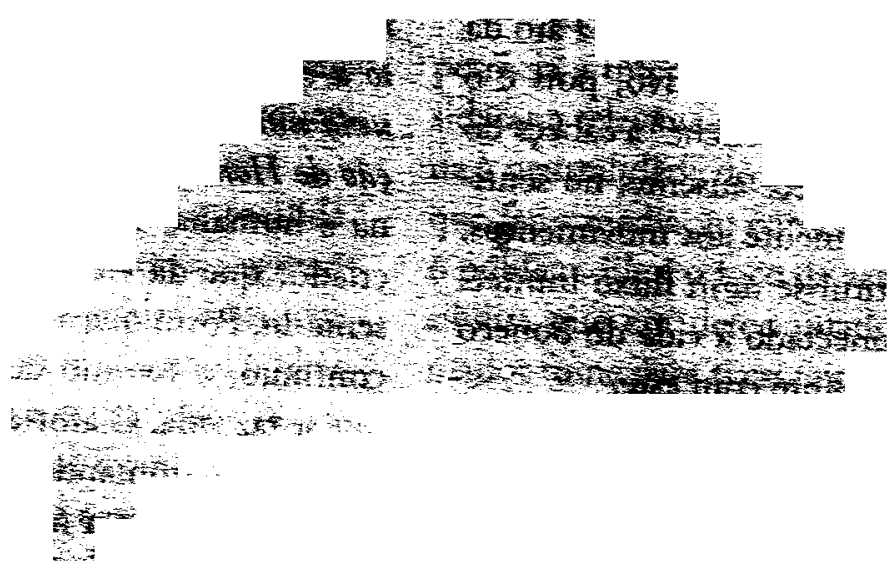

